\title{
CZY ZABYTKI TECHNIKI I INŻYNIERII TO W POLSCE WCIĄŻ DZIEDZICTW0 „DRUGIEJ KATEGORII”? \\ $\square$ RYS HISTORYCZNY ORAZ AKTUALNE PROBLEMY ${ }^{1}$ Are monuments of technology and engineering in Poland still a "second-class" heritage? Historical outline and current problems Bartosz M. Walczak*
}

SUMMARY: This article explains issues pertaining to protection of materials that are relevant by their use or their invention in the view of changing socio-economic conditions and evolution of approaches to historic preservation. The author discusses sources of problems, provides historical outline of research studies and presents the current situation in Poland. Furthermore, the article focuses on problems related to the definition of industrial and engineering heritage and assessment of its values. Particular emphasis was placed upon authenticity and classification of materials that are relevant by their use or their invention. The author of this article also highlights that this type of heritage and other historic monuments and sites should be considered equal. Additionally, this paper suggests how crucial the concept of integrated areabased protection is to efficient historic preservation of materials that are relevant by their use or their invention.

KEY WORDS: industrial heritage, authenticity, valorisation, integrated protection.

\section{Inność. Geneza zabytków techniki}

Wyodrębnienie kategorii zabytków inżynierii i techniki z całego zasobu zabytków wynika ze ścisłego ich powiązania z postępem technologicznym i rozwojem społeczno-gospodarczym, jaki nastąpił w przeszłości historycznej wskutek zastosowania w praktyce praw przyrody. Industrializacja bardzo silnie przyczyniła się do urbanizacji oraz w istotny sposób wpłynęła na kształtowanie miejsc i regionów związanych z przemysłem. W konsekwencji na długi czas określiła ich tożsamość kulturową i przestrzenną² a jej spuścizna odgrywa istotną rolę w kształtowaniu się współczesnych doktryn konserwatorskich (wiek obiektów zabytkowych w znakomitej większości nie przekracza schyłku XVIII stulecia, czyli początków rewolucji przemysłowej).

Rozwój przemysłu w jego wczesnej fazie zbiegł się w czasie ze wzrostem zainteresowania przeszłością i jej „pamiątkami”, oraz kształtowaniem podwalin dla rodzącej się wówczas dyscypliny, stawiającej sobie za cel ochronę zabytków. Industrializacja i jej skutki były jednak początkowo stawiane

* PhD Arch. Bartosz M. Walczak, prof. TUL. Department of History of Architecture, Revitalization and Conservation of Monuments, Institute of Architecture and Urban Planning, Technical University of Lodz https://orcid.org/ 0000-0002-9429-9626

1 Niniejszy tekst powstał w oparciu o wyniki prac zespołu w składzie: Waldemar Affelt, Piotr Gerber, Robert Kola, Bartosz M. Walczak, który w ramach realizacji Krajowego Programu Ochrony Zabytków i Opieki nad Zabytkami na lata 2014-2017 przygotował dla Ministerstwa Kultury i Dziedzictwa Narodowego opracowanie dotyczące standardów postępowania konserwatorskiego przy zabytkach inżynierii i techniki.

2 Opania S., Tożsamość a wizerunek obszarów poprzemysłowych. Przykład aglomeracji górnośląskiej, Politechnika Śląska, Gliwice 2012. 
w opozycji do zabytków, które znalazły się w kręgu zainteresowania ówczesnych konserwatorów. Znakomitą ilustracją zjawiska jest książka autorstwa Augusta W. Pugina, wydana w 1836 roku pod znamiennym tytułem Kontrasty ${ }^{3}$. W publikacji zamieszczone zostały plansze zestawiające „piękno” średniowiecznej architektury z „brzydotą” ówczesnych dokonań. Jedna z ilustracji ukazuje tradycyjne europejskie miasto kupieckie z historycznie ukształtowaną sylwetą, strukturą przestrzenną i społeczną, zniekształconą przez budynki produkcyjno-magazynowe oraz kominy ${ }^{4}$. Chociaż pierwsze przejawy ochrony wybranych obiektów przemysłowych sięgają lat 20. i 30. XX wieku, to głębsza zmiana stosunku do spuścizny industrialnej nastąpiła dopiero trzy dekady później. Wiązało się to z postępującym procesem upadku tradycyjnych gałęzi przemysłu w Europie oraz stopniowym docenianiem wartości kulturowych architektury dziewiętnastowiecznej.

\section{Badania i zaniedbania. Sytuacja zabytków techniki w Polsce w ujęciu historycznym}

Początki muzealnictwa technicznego w Polsce sięgają drugiej połowy XIX wieku. Z tej tradycji wyrosły dążenia do zabezpieczania zabytków in situ, czego wybitny przykład stanowi walcownia i pudlingarnia w Sielpi Wielkiej, będąca pierwszym w naszym kraju zakładem objętym kompleksową ochroną, co nastąpiło już w 1934 roku ${ }^{6}$. Dwa lata później rozpoczęła się działalność inwentaryzacyjna sekcji budownictwa przemysłowo-gospodarczego w Zakładzie Architektury Polskiej na Wydziale Architektury Politechniki Warszawskiej. Te pionierskie na arenie międzynarodowej działania z zakresu ochrony i dokumentacji zabytków techniki przerwał wybuch drugiej wojny światowej. Natomiast po jej zakończeniu, wobec konieczności odbudowy kraju, problematyka dziedzictwa przemysłowego nie była priorytetem. Jak wykazała ankieta przeprowadzona w 1954 roku przez redakcję Kwartalnika Historii Kultury Materialnej, zabytki techniki i przemysłu na ogół nie zostały zauważone przez konserwatorów wojewódzkich ${ }^{7}$. Ta sytuacja zaczęła się jednak stopniowa zmieniać. W 1955 roku w warszawskim Pałacu Kultury i Nauki zorganizowana została wielka wystawa Postęp techniczny w służbie człowieka, będąca zalążkiem przyszłego muzeum techniki. W tym samym roku w Instytucie Historii Kultury Materialnej PAN podjęto szeroko zakrojone prace inwentaryzacyjne, których rezultatem jest ukazujący się od 1958 roku

3 Pugin A.W., Contrasts with an introduction by H. R. Hitchcock, Leicester University Press, Leicester 1969.

4 Walczak B. M., Zespoły fabryczno-mieszkalne w europejskim przemyśle włókienniczym w latach 1771-1914: geneza, rozwój, typologia, Politechnika Łódzka, Łódź 2010.

5 Najwcześniej nastąpiło to w kolebce rewolucji przemysłowej - Wielkiej Brytanii, gdzie na przełomie lat 50. i 60. XX wieku dynamicznie zaczęła się rozwijać „archeologia przemysłowa”. Ten nieco mylący termin obejmował zarówno prace stricte badawcze, dotyczące zabytków przemysłu i techniki, jak i ochronę budynków iurządzeń przemysłowych. Określenia takiego użyłjako pierwszy najprawdopodobniejprofesor Donald Dudley z Uniwersytetu Birmingham, a w piśmiennictwie po raz pierwszy pojawiło się w artykule Michaela Rixa (Rix M., „Industrial archaeology”, The Amateur Historian, nr 8, 1955, s. 225-229). Warto zauważyć, iż w tym samym czasie również w Polsce prowadzono badania archeologiczne poświęcone obiektom przemysłowym w 1956 roku odsłonięte zostały relikty siedemnastowiecznej huty ołowiu w Zalesiu na kielecczyźnie (Radwan M., „Badania terenowe nad zabytkami hutnictwa żelaznego w Zagłębiu Staropolskim, Kwartalnik Historii Nauki i Techniki, 1956, s. 452).

6 Radwan M., „Zabytkowa pudlingarnia i walcownia w Sielpi Wielkiej”, Kalendarz Górniczo-Hutniczy, Katowice 1938.

7 Pazdur J., „Zagadnienia ochrony i konserwacji zabytków techniki”, Ochrona Zabytków, r. X., z. 2(37), 1957, s. 113-122. 
Katalog zabytków budownictwa przemysłowego w Polsce. Kolejna dekada przyniosła nową ustawę, w której uwzględniono ochronę obiektów inżynierii i techniki ${ }^{8}$, a w ślad za tym konferencję Zabytki i tradycje techniki w Tysiąclecie Państwa Polskiego (1964) oraz Rok Muzeów i Zabytków Techniki (1965). Chociaż równolegle ukazywały się drukiem artykuły omawiające wybrane zagadnienia lub obiekty, to jednak pierwsze znaczące publikacje zostały wydane dopiero na początku lat 70. XX wieku9. Należy tutaj podkreślić zasługi profesora Jana Pazdura, z którego inicjatywy podjęto większość przytoczonych powyżej działań.

Widoczny również w tym okresie wzrost zainteresowania obiektami wzniesionymi po 1850 roku przyczynił się do zwrócenia uwagi na budynki zakładów przemysłowych. Znalazło to odzwierciedlenie wwystąpieniach nakonferencjach naukowych, w publikacjach, a nawet wdziałalności wystawienniczej ${ }^{10}$. Jednak bardzo często obiekty te poddawano ocenie na podstawie takich samych kryteriów jak inne zabytki architektury, nie uwzględniając ich specyfiki (o której będzie jeszcze szerzej mowa poniżej). Wobec ewidentnego braku przygotowania służb konserwatorskich w zakresie ochrony zabytków technikiiinżynierii, Politechnika Wrocławskajużw 1971 roku powołałaZakład Historii NaukiiTechniki w ramach Wydziału Architektury. Jednostka ta rozpoczęła swoją działalność od dokumentacji zabytków dolnośląskiego przemysłu.

W tym okresie nawiązano także ożywione kontakty międzynarodowe, a przedstawiciele Polski aktywnie uczestniczyli w pierwszych kongresach ochrony zabytków techniki, które doprowadziły do powołania TICCIH. Na początku kolejnej dekady podkreślano, że zabytki techniki są istotnym świadectwem kultury materialnej oraz przedmiotem zainteresowania nauki. Świadectwem takiego podejścia mogą być liczne konferencje w całości poświęcone tej problematyce, ale przede wszystkim fakt utworzenia w 1982 roku stanowiska do spraw zabytków techniki w Ośrodku Dokumentacji Zabytków w Warszawie ${ }^{11}$. Do widocznych rezultatów można zaliczyć wprowadzone ówcześnie zmiany w zakresie ewidencji zabytków - dla ruchomych zabytków techniki opracowano odrębny wzór karty, zaś dla zabytków nieruchomych - aneks do instrukcji wypełniania kart, uwzględniający specyfikę obiektów przemysłowych. W tym samym czasie w środowisku Polskiego Towarzystwa Historii Techniki narodził się pomysł stworzenia Karty ochrony zabytków techniki, uwzględniającej specyfikę tego typu dziedzictwa, w tym metody klasyfikacji, kategoryzacji oraz kryteria oceny ${ }^{12}$.

Mimo, wydawałoby się, tak dobrze zorganizowanego systemu dokumentacji zabytków techniki

Ustawa z dnia 15 lutego 1962 r. o ochronie dóbr kultury (Dz. U. 1962 Nr 10 poz. 48), której art. 4. pkt 6 obejmował ochroną „obiekty techniki i kultury materialnej”.

9 Jasiuk J., Pazdur J. (red.), Muzea i zabytki techniki w Polsce, Wydawnictwa Naukowo-Techniczne, Warszawa 1970.

10 M.in.: Problemy ochrony architektury najnowszej (1850-1939), Biblioteka Muzealnictwa i ochrony Zabytków, seria B, tom XXIX, Ministerstwo Kultury i Sztuki - Zarząd Muzeów i Ochrony Zabytków - Ośrodek Dokumentacji Zabytków, Warszawa 1971; Krzyżanowski L., „Wystawa konserwatorska »Zabytkowa architektura i budownictwo przemystowe Łodzi«, listopad 1971", Ochrona Zabytków, r. XXV, z. 1(96), 1972, s. 55-57.

11 Ochrona zabytków techniki, Biblioteka Muzealnictwa i Ochrony Zabytków, seria B, tom LIX, Ośrodek Dokumentacji Zabytków, Warszawa 1980; Kalinowski W., „Ochrona i konserwacja zabytków techniki w Polsce", Ochrona Zabytków, r. XXXVIII, z. 3-4 (150-151), 1985, s. 163-170.

12 Paździor M., „Zagadnienia ochrony zabytków techniki w okresie modernizacji przemystu”, Ochrona Zabytków, r. XL, z. 4 (159), 1987, s. 332-333; Rosińska K., „Ewidencja zabytków techniki”, Ochrona Zabytków, r. XLI, z. 4 (163), 1988, s. 224-227. 
oraz ugruntowanej świadomości ich znaczenia - przynajmniej wśród specjalistów zajmujących się ochroną i konserwacją dziedzictwa, dziedzictwo przemysłowe okazało się bezbronne wobec procesów deindustrializacyjnych zachodzących w Polsce od lat 90. XX wieku. Należy jednak podkreślić, że w wyniku transformacji polityczno-gospodarczej, zapoczątkowanej w naszym kraju w 1989 roku, proces zmian w technologiach produkcji przebiegał znacznie szybciej niż w większości krajów zachodnioeuropejskich. Dotyczyło to wielu aspektów, rozwoju społecznego i gospodarczego, ale najbardziej było - i nadal jest - dostrzegalne w obrębie miast i regionów o przemysłowym rodowodzie. Likwidacja nieekonomicznych gałęzi produkcji spowodowała znaczne spowolnienie, a niekiedy upadek gospodarczy wielu miejscowości wyrosłych w okresie przemian rewolucji przemysłowej. Dziedziny przemysłu - niegdyś decydujące o rozwoju, jak włókiennictwo w Łodzi lub na Dolnym Śląsku, w ciągu ostatnich dwudziestu lat przestały istnieć. Podobny proces dotyczy górnictwa węgla kamiennego i związanego z nim hutnictwa na Górnym Śląsku.

Jednym $\mathrm{z}$ istotnych problemów związanych $\mathrm{z}$ reorganizacją gospodarki jest pozbawienie funkcji terenów dawnych zakładów przemysłowych. Przedsiębiorstwa, wpływające niegdyś na lokalny rozwój gospodarczy, stały się zdegradowaną przestrzenią, stanowiącą przeszkodę w dalszym rozwoju.

Rozumienie potrzeby ochrony dziedzictwa przemysłowego w trakcie likwidacji nieefektywnego przemysłu w Polsce było w zasadzie nieobecne. Najczęściej proces zamykania historycznych zakładów odbywał się bez przeprowadzenia dokumentacji i fachowej oceny. Proces likwidacji lokalnego dziedzictwa przemysłowego przebiegał zazwyczaj bez udziału służb odpowiedzialnych za ochronę zabytków. Brak nadzoru nad likwidacją i przekształceniami historycznych zakładów doprowadził do zniszczenia bogatego zasobu zabytkowych technologii, ciągów produkcyjnych, maszyn i urządzeń.

W wyniku przekształceń likwidowanych zakładów przemysłowych, nienadzorowanych przez służby konserwatorskie, zasób materialnego dziedzictwa przemysłowego znacząco zmalał. Obecnie niestety trudno poznać historię rozwoju wielu ważnych historycznie dziedzin przemysłu, decydujących o rozwoju regionów. $Z$ tego względu działania na rzecz zachowania materialnych świadectw przemysłowego rozwoju nabierają szczególnej wagi.

Jednocześnie ostatnie lata przyniosły wzrost świadomości wartości dziedzictwa przemysłowego. Prowadzonesąpracenadhistoriąrozwojuprzemysłowegoregionów, atakżepracenaddokumentowaniem materialnych pozostałości po dawnej aktywności przemysłowej ${ }^{13}$. Projekty adaptacji przestrzeni i obiektów poprzemysłowych na różne nowe funkcje stały się istotnym, a nawet oczywistym działaniem $\mathrm{w}$ ramach odnowy wielu polskich miast ${ }^{14}$. Niestety nie przekłada się to na jakość prowadzonych przebudów. Co więcej, działania te niejednokrotnie przyczyniają się do zatarcia istotnych wartości zabytkowych. Nadal zatem istnieje potrzeba sprecyzowania przedmiotu oraz metod ochrony zabytków techniki i inżynierii ${ }^{15}$.

13 Na przykład: Gerber P., Architektura przemysłowa Wrocławia w początkach industrializacji, Wrocławskie Towarzystwo Naukowe, Wrocław 2007; Rygus P., Zarys historyczny hutnictwa cynku na Górnym Śląsku w latach 1798-1980, Fundacja Ochrony Dziedzictwa Przemysłowego Śląska, Katowice 2015.

14 Walczak B.M. (red.), Rewitalizacja miast poprzemysłowych - rola dziedzictwa kulturowego, Łódzka Okręgowa Izba Inżynierów Budownictwa/Politechnika Łódzka, Łódź 2006.

15 Kępczyńska-Walczak A. (red.), Zakres i granice ingerencji konserwatorskiej w adaptacji obiektów i zespołów poprzemysłowych, Politechnika Łódzka / Urząd Miasta Łodzi 2012. 


\section{W poszukiwaniu definicji zabytku techniki}

Ze względu na charakter i zakres opracowania należy uznać, że zabytki inżynierii i techniki powinny odpowiadać definicji zawartej w podstawowym polskim dokumencie odnoszącym się do ochrony zabytków, jakim jest obowiązująca ustawa ${ }^{16}$. Artykuł 3. precyzuje, co w świetle obowiązującego prawa jest zabytkiem: „1) zabytek - nieruchomość lub rzecz ruchoma, ich części lub zespoły, będące dziełem człowieka lub związane z jego działalnością i stanowiące świadectwo minionej epoki bądź zdarzenia, których zachowanie leży w interesie społecznym ze względu na posiadaną wartość historyczną, artystyczną lub naukową; 2) zabytek nieruchomy - nieruchomość, jej część lub zespół nieruchomości, o których mowa w pkt 1;3) zabytek ruchomy - rzecz ruchoma, jej część lub zespół rzeczy ruchomych, o których mowa w pkt 1;4) zabytek archeologiczny - zabytek nieruchomy, będący powierzchniową, podziemną lub podwodną pozostałością egzystencji i działalności człowieka, złożoną z nawarstwień kulturowych i znajdujących się w nich wytworów bądź ich śladów albo zabytek ruchomy, będący tym wytworem".

Należy podkreślić, że zabytki techniki, inżynierii i przemysłu mogą mieścić się w każdej z wyżej wymienionych kategorii. Uwzględniając podział typologiczny, zawarty w artykule 6. Ustawy, należy zauważyć, iż zabytki inżynierii i techniki mogą być nie tylko literalnie wymienionymi „obiektami techniki,azwłaszczakopalniami, hutami, elektrowniamiiinnymizakładamiprzemysłowymi”,lecztakże mogą stanowić zespoły budowlane (czyli „powiązane przestrzennie grupy budynków wyodrębnione ze względu na formę architektoniczną, styl, zastosowane materiały, funkcję, czas powstania lub związek z wydarzeniami historycznymi”), a nawet układy urbanistyczne („przestrzenne założenia zawierające zespoły budowlane, pojedyncze budynki i formy zaprojektowanej zieleni, rozmieszczone w układzie historycznych podziałów własnościowych i funkcjonalnych, w tym ulic lub sieci dróg"), czy krajobrazy kulturowe („przestrzenie historycznie ukształtowane w wyniku działalności człowieka, zawierające wytwory cywilizacji oraz elementy przyrodnicze"). Natomiast zabytki ruchome w świetle Ustawy mogą być „wytworami techniki, a zwłaszcza urządzeniami, środkami transportu oraz maszynami i narzędziami świadczącymi o kulturze materialnej, charakterystycznymi dla dawnych i nowych form gospodarki, dokumentującymi poziom naukiirozwoju cywilizacyjnego". Co więcej, uwzględnionetakże w Ustawie dziedzictwo niematerialne, może się również odnosić do dziedzictwa poprzemysłowego.

Warto powyższe określenie przedmiotu niniejszego opracowania zestawić z innymi definicjami zabytków inżynierii i techniki występującymi w piśmiennictwie. Zabytki techniki - jako ważny element dziedzictwa kulturowego, niosącego ze sobą określone wartości, uwzględniane są w szeregu dokumentów o randze międzynarodowej, w tym w konwencjach, wytycznych UNESCO, stanowiskach Rady Europy. W pierwszej kolejności należy jednak odnieść się do Karty Tagilskiej (dokument przyjęty w 2003 podczas kongresu TICCIH stanowi zbiór wytycznych i zaleceń z zakresu ochrony zabytków techniki i inżynierii). Dokument ten rozróżnia dziedzictwo techniki - rozumiane jako element dziedzictwa kultury związany z historią myśli technicznej - oraz istniejące w jego obrębie zabytki przemysłu, zabytki inżynierii oraz zabytki techniki.

Zgodnie z tym dokumentem zabytki przemysłu ,zawierają pozostałości kultury przemysłowej o wartości historycznej, technicznej, społecznej, architektonicznej lub naukowej. W skład jego wchodzą budynkiimaszyny,warsztaty,zakładyprodukcyjneifabryki,kopalnieizakładyobróbkiiuszlachetniania,

16 Ustawa z dnia 23 lipca 2003 r. o ochronie zabytków i opiece nad zabytkami (Dz.U. 2003 Nr 162 poz. 1568 z poźn. zm.). 
magazyny i składy, miejsca wytwarzania, przekazywania i wykorzystania energii, transport i jego infrastruktura, a także miejsca o funkcji socjalnej, związanej z przemysłem, jak np. zabudowania mieszkalne, miejsca praktyk religijnych i modlitwy oraz edukacji"17.

Zabytki inżynierii opisuje jako obiekty, które „sklasyfikowane zostały podług tradycyjnych dyscyplin nauk technicznych, np. jako inżynieria mechaniczna - zajmująca się budową i eksploatacją maszyn; budowlana-konstrukcjamibudynkówibudowlimostowych, drogowych, kolejowych, wodnych (np. tam, kanałów, śluz, jazów, nabrzeży, latarni morskich, wież wiertniczych), a także produkcja wyrobów budowlanych, ich transport i montaż, kontrola laboratoryjna cech materiałów i wyrobów budowlanych; inżynieria chemiczna; inżynieria elektrotechniczna; inżynieria energetyczna; inżynieria budowy okrętów; inżynieria awiacji (lotnicza i kosmiczna); inżynieria informacji i telekomunikacji itd."

Natomiast zabytki techniki to „badane metodami historii, czyli technika w określonych kontekstach np. postęp techniczny $\mathrm{w}$ danej epoce (np. prehistoria, starożytność, średniowiecze, renesans, rewolucja naukowa, rewolucja przemysłowa I, II, III); techniczne i społeczne środowisko pracy (ergonomia, organizacja, narzędzia, bezpieczeństwo i stosunki pracy); techniki wojskowe obrony i ataku; technika edukacyjna i edukacja techniczna; kolekcjonerstwo artefaktów technicznych imuzealnictwo techniczne; technika w ujęciu rodzajowym (tzw. gender studies), np.kobiety-wynalazcy".

Kolejny istotny dokument to pryncypia ochrony dziedzictwa przemysłowego, sformułowane wspólnie przez TICCIH i ICOMOS w 2011 w Dublinie ${ }^{18}$. W jego preambule czytamy: „Na całym świecie, wielka różnorodność miejsc, struktur, miast i osiedli, obszarów, krajobrazów i szlaków stanowi świadectwo ludzkiej działalności w zakresie przemysłowego wydobycia oraz produkcji. $\mathrm{W}$ wielu przypadkach to dziedzictwo jest wciąż w użyciu a industrializacja jest nadal aktywnym procesem dającym poczucie historycznej ciągłości, ale gdzie indziej jest to jedynie archeologiczne świadectwo dawnej działalności i technologii. Oprócz dziedzictwa materialnego, dotyczącego technologii i procesów przemysłowych, inżynierii, architektury oraz urbanistyki, należy uwzględnić wymiar niematerialny: umiejętności, wspomnień, życia społecznego robotników i ich społeczności”.

Wśród opracowań polskich, poświęconych omawianej problematyce, warto zwrócić uwagę na definicję zaproponowaną przez Waldemara Affelta: „Pojęcie zabytku techniki obejmuje ruchome i nieruchome obiekty materialne, które Człowiek stworzył, aby przetrwać i poprawiać warunki swojej egzystencji. Są one zasadniczym składnikiem cywilizacji i kultury, dokumentując rozwój społecznoekonomiczny, postęp naukowo-techniczny i/lub znaczące wydarzenia historyczne. Pojęcie to obejmuje nie tylko wielkie dzieła geniuszu ludzkiego, ale również skromne obiekty, które z upływem czasu stały się w skali lokalnej miejscami o znaczeniu kulturowym. Z dobrami materialnymi na ogół związane są elementy dziedzictwa niematerialnego"19.

Definicję zabytków techniki podaje także Mały słownik ochrony zabytków, w którym przedstawiono je jako obszary, miejsca, obiekty i przedmioty ważne dla historii techniki i przemysłu

17 To tłumaczenie i następne za: Affelt W., „Dziedzictwo techniki, jego różnorodność i wartości”, Kurier Konserwatorski, 5/2009, s. 5-20.

18 Joint ICOMOS-TICCIH Principles for the Conservation of Industrial Heritage Sites, Structures, Areas and Landscapes, Dublin 2011.

19 Affelt W., Karta TECHNITAS w sprawie zachowania dziedzictwa techniki i miejsc je upamiętniających, Wydawnictwo Wydziału Sztuk Pięknych Uniwersytetu Mikołaja Kopernika, Toruń 2014, s. 11. 
oraz zjawisk społecznych i technicznych związanych bezpośrednio z ich rozwojem. Zaliczają się do nich: zakłady produkcyjne, maszyny i narzędzia, urządzenia i środki transportu, komunikacji i łączności oraz wyroby przemysłowe. W przypadku wyrobów przemysłowych na ich wartości zabytkowe składają się nie tylko czynniki wskazujące na poziom techniki w danym okresie historii, lecz także ich znaczenie $\mathrm{w}$ życiu, kształtowaniu postępu cywilizacyjnego i kulturalnego $0^{20}$.

Przede wszystkim należy podkreślić, że przytoczone powyżej definicje stanowią istotne poszerzenie ustawowego określenia zabytków inżynierii i techniki. Reprezentują bardziej holistyczne ujęcie, uwzględniającekontekstspołeczno-gospodarczy.Podkreślajątakżedużą różnorodnośćobiektów, które mimo, że związane z przemysłem, stwarzają skrajnie odmienne problemy konserwatorskie (na przykład doświadczenia zgromadzone przy pracach konserwatorskich i adaptacyjnych parterowej hali walcowni mają znikome zastosowanie w przypadku wielokondygnacyjnej przędzalni).

Powyższe definicje podkreślają również znaczenie wyposażenia technologicznego. Jednak w niedostatecznym stopniu wskazują na znaczenie zachowania urządzeń in situ. Tak jak wartość zabytkowego pałacu jest nieporównanie wyższa, gdy zachował się on z autentycznym wyposażeniem, tak również tylko zakład przemysłowy z zachowanymi urządzeniami i maszynami pozwala na pełne zrozumienie przyjętych rozwiązań funkcjonalnych, przestrzennych i konstrukcyjnych.

Niestety zabytki przemysłu wciąż są postrzegane przede wszystkim jako architektoniczne pozostałości dawnych fabryk, a nie jako kompleksy, składające się z procesów technologicznych prowadzonych w oparciu o zespół urządzeń, gdzie budynki stanowią jedynie obudowy realizowanych technologii wytwarzania, co ma kolosalne znaczenie dla prawidłowej oceny ich wartości.

\section{Koń jaki jest, każdy widzi? Czyli o nieoczywistej wartości zabytków inżynierii i techniki}

Za fundament współczesnej teorii konserwatorskiej uznaje się Kartę Wenecką, przyjętą w 1964 roku przez II Międzynarodowy Kongres Architektów i Techników Zabytków. W tym samym okresie Walter Frodl dokonał podsumowania ówczesnej wiedzy w zakresie wartościowania obiektów zabytkowych, zapoczątkowanej rozważaniami Aloisa Riegla z przełomuXIXiXX stulecia ${ }^{21}$.Jednak wraz ze znaczącym wzrostem zróżnicowania typologicznego oraz liczby obiektów będących przedmiotem zainteresowania konserwatorów pojawiły się głosy sugerujące, że konieczne jest nowe spojrzenie na metodykę oraz metody ochrony i konserwacji zabytków. Zgodnie z najnowszymi tendencjami waloryzacjadziedzictwaniepowinnasięograniczaćjedyniedoocenywartościkulturowych. Napoczątku XXI stulecia David Throsby, specjalizujący się w zagadnieniach związanych z ekonomiką kultury, podkreślił,że „Jeślijuż ekonomiściodważą sięwejśćna »święty«teren decyzjikonserwatorskichiwskazać na pewne ich ekonomiczne konsekwencje, traktowani są często jak intruzi i przyjmowani z niechęcią, tak jakby sprawy związane $\mathrm{z}$ dziedzictwem były poza zasięgiem ekonomii. Analiza ekonomiczna może jednak, jeśli jest wrażliwa na wartości kulturowe, z którymi ma do czynienia, zaangażować się $\mathrm{w}$ wiele kwestii w tej dziedzinie"22. W konsekwencji tego typu rozważań autor ten przedstawił

20 Kurzątkowski M., Mały słownik ochrony zabytków, Spotkania z Zabytkami, Warszawa 1989.

${ }_{21}$ Frodl W., Pojęcia i kryteria wartościowania zabytków, Ministerstwo Kultury i Sztuki, Warszawa 1966; Alois Riegl, Georg Dehio i kult zabytków, (przekład i wstęp Ryszard Kasperowicz), Oficyna Wydawnicza „Mówią wieki”,Warszawa 2002.

22 Throsby D., Economics and Culture, Cambridge University Press, Cambridge 2001, s. 74-75, tłum. MurzynKupisz M., „Barbarzyńca w ogrodzie? Dziedzictwo kulturowe widziane z perspektywy ekonomii”, Zarządzanie Publiczne, nr 3 (13), 2010, s. 19-31. 
propozycję wartościowania uwzględniającą wartości społeczne.

Debata na ten temat toczy się także w Polsce. Spośród polskich badaczy interesujące są propozycje Michała Witwickiego ${ }^{23}$, który wskazał znaczenie wartości użytkowych i technicznych, a także Waldemara Affelta, proponującego oceniać dziedzictwo nie tylko na podstawie wartości kulturowych, ale także społeczno-ekonomicznych. Szczególnie ta ostatnia jest godna uwagi, gdyż dotyczy bezpośrednio ochrony dziedzictwa przemysłowego ${ }^{24}$.

Zgodnie z ustawą zabytki chroni się ze względu na ich wartości kulturowe, historyczne, naukowe i artystyczne. Dlatego szczególne znaczenie ma rozpoznanie obiektu na etapie obejmowania go ochroną, a przynajmniej przed przystąpieniem do prac konserwatorskich. Istotne jest, aby ocena była sparametryzowana, co powinno zapewnić jej obiektywizm.

Wartość historyczna obiektu może się odnosić nie tylko do czasu powstania, ale także wydarzeń i osób związanych z zabytkiem. W przypadku wartości naukowej w pierwszej kolejności należy zwrócić uwagę na unikatowość rozwiązań, ich integralność w obrębie obiektu/zespołu; następnie powinno się poddać ocenie znaczenie zabytku dla miejsca. W przypadku zabytków techniki niezwykle istotna jest ocena rozwiązań inżynierskich (w zakresie konstrukcji i technologii), gdyż pierwiastek twórczy w technice towarzyszy wyłącznie zjawiskom takim, jak wprowadzanie nowych surowców i środków pracy, nowej technologii i wytworów użytkowych. Tak nakreśloną wartość postępu można określić w wyniku przeprowadzenia porównawczej analizy ilościowej i jakościowej w oparciu o wskaźniki techniczno-ekonomiczne. Przy braku danych metrykalnych uwzględnienie kryteriów wskazujących na postęp techniczny wymaga dobrej znajomości historii danej dziedziny techniki, ustalenia cech technicznych obiektu, jego miejsca i roli w szeregu technologicznym i typologicznym.

Aczkolwiek byłoby to jednak zbytnie zawężenie - zabytki techniki mogą także reprezentować wartości dla historii produkcji, wyrażające się przede wszystkim poprzez urządzenia/maszyny; wyposażenie obiektów oraz ich rozplanowanie przestrzenne. Niezwykle istotne dla oceny wartości zabytkowej obiektu są wszelkie zmiany, jakie zaszły w trakcie jego eksploatacji. Na ogół bowiem obiekty techniki nie występują w postaci pierwotnej (wzorcowej), a kolejne modernizacje doprowadzają niekiedy do zupełnego zatarcia pierwotnych cech technicznych, układu funkcjonalnego i zdekompletowania poszczególnych elementów składowych. Dlatego należy zwrócić szczególną uwagę na zmiany konstrukcyjne, materiałowe oraz zmiany systemu energetyki. Przy obiektach nieruchomych istotne są zmiany układu przestrzennego zabudowy, zmiany gabarytów budowli, remonty wnętrz, które prowadziły do zmiany warunków pracy itp. Odnotować też należy wszelkie wymiany maszyn roboczych, modernizację urządzeń mechanicznych, przekształcenia w systemie transportu wewnątrz zakładu. Każda z tych zmian może mieć wartość dokumentalną (dokumentem może być poszczególny element obiektu technicznego bądź też cały, ewolucyjnie ukształtowany obiekt).

Rozpoznanie wartości artystycznej powinno uwzględniać fakt, że może ona być intencjonalna, jak

${ }^{23}$ Witwicki M., „Kryteria oceny wartości zabytkowej obiektów architektury jako podstawa wpisu do rejestru zabytków", Ochrona Zabytków, nr 1, 2007, s. 77-98.

24 Affelt W., „O wartościach architektury przemysłowej (i nie tylko...)” w: Szmygin B. (red.), Wartościowanie zabytków architektury, PKN ICOMOS - Muzeum Pałac w Wilanowie, Warszawa 2013, s. 17-36; Tenże, „Wartościowanie dziedzictwa techniki: rozpoznawanie, interpretacja, zachowanie” w: Szmygin B. (red.), Wartościowanie w ochronie i konserwacjizabytków, PKN ICOMOS - Biuro Stołecznego Konserwatora Zabytków Politechnika Lubelska, Warszawa-Lublin 2012, s. 7-16. 
Czy zabytki techniki i inżynierii to w Polsce wciąż dziedzictwo „drugiej kategorii”? ...

i mimowolna (np. efekt upływu czasu). Podobnie jak w przypadku innych typów zabytków znaczenie będzie miała oczywiście osoba twórcy. Wreszcie nie wolno zapominać o wartościach niematerialnych, a w szczególności o znaczeniu społecznym zabytku, tradycjach, nazewnictwie, języku a także dawnych umiejętnościach (obsługa maszyn i urządzeń), które powinno się chronić w powiązaniu z materialnym obiektem.

\section{Od stereotypu do kategoryzacji. Specyfika zabytków techniki}

Z zaprezentowanego powyżej przeglądu badań nad zabytkami techniki oraz ich ochrony i konserwacji w Polsce wynika, że kilkakrotnie podejmowano próby wprowadzenia spójnego systemu systematyki dla obiektów związanych z inżynierią i produkcją.

Jedna z pierwszych prób systematyzacji spuścizny przemysłowo-technicznej pod kątem wartości kulturowych zakładała wyodrębnienie trzech grup obiektów: pierwszą stanowić miały obiekty zdemontowane, drugą - czynne lub unieruchomione, ale posiadające wyposażenie, a trzecią - ruchome środkipracyiprodukty ${ }^{25}$.Poupływiebliskosześćdziesięciulatzbólemnależyprzyznać,żestanzachowania dziedzictwa przemysłowego w Polsce sprawia, iż zdecydowana większość obiektów mieściłaby się w pierwszej kategorii.

Podczas gdy w latach 50. XX wieku problemem była niemożność prowadzenia skutecznej ochrony czynnych zakładów produkcyjnych, to obecnie można już tylko zabiegać o zachowanie myśli technicznej zawartej w koncepcji zakładu przemysłowego, jego lokalizacji, układzie przestrzennym i rozwiązaniach architektoniczno-konstrukcyjnych.

Nasuwa się smutna refleksja, że wieloletnia, dobrze ugruntowana tradycja badań nad historią techniki i kultury materialnej, nie przełożyła się na sukcesy w ochronie zabytków techniki. Jednak, żeby prowadzić skuteczną politykę konserwatorską, potrzebny jest dostęp do rzetelnej wiedzy ${ }^{26}$. Niezbędna jest również popularyzacja dziedzictwa oraz edukacja społeczeństwa. W tych kwestiach działania dotyczące zabytków techniki i inżynierii także pozostawiają wiele do życzenia. Bardzo dobrze o tym świadczy przykład zaczerpnięty z uruchomionego w 2015 roku portalu e-Zabytek.pl, prowadzonego przez Narodowy Instytut Dziedzictwa. Użytkownicy tego serwisu mogą zapoznawać się z polskim dziedzictwem za pośrednictwem interaktywnej mapy. Zespół fabryczno-mieszkalny K. Scheiblera w Łodzi obejmuje między innymi budynek straży pożarnej, który na mapie opatrzono znakiem wskazującym na jego przemysłowy charakter. Po otworzeniu okna z dodatkowym opisem można dowiedzieć się, iż jest to „inny budynek przemysłowy, produkcyjny lub magazynowy”, co $\mathrm{w}$ świetle przytoczonych powyżej informacji na temat zabytku wydaje się chybioną klasyfikacją. Co ciekawe, sąsiadujące $\mathrm{z}$ remizą magazyny fabryczne oznaczono innym symbolem, klasyfikującym je jako budynki gospodarcze. Nie wskazuje to (zwłaszcza w kontekście oznaczenia remizy jako obiektu przemysłowego) na ich związek z sąsiednią fabryką, a tymczasem były to najważniejsze dla całego przedsiębiorstwa składy surowców. Równie kontrowersyjna jest klasyfikacja analogicznego do budynku straży pożarnej na Księżym Młynie obiektu w obrębie dawnych zakładów I. K. Poznańskiego. W tym przypadku przy obrysie budynku umieszczono jeszcze inny piktogram, zarezerwowany do budynków

25 Pazdur J., „Zagadnienia ochrony $i$ konserwacji ...”

${ }^{26}$ por.: Kępczyńska-Walczak A. Zarządzanie dziedzictwem kulturowym w społeczeństwie opartym na wiedzy, Politechnika Łódzka, Łódź 2014. 
publicznych (sic!), a opis jednoznacznie precyzuje zabytek jako „remizę"27.

Tenjedenprzykładdobitniewskazuje,jakwielejestdozrobienia-nietylkowzakresieporządkowania oraz weryfikacji informacji o zabytkach w Polsce, ale nawet w odniesieniu do terminologii je opisującej. Kategoryzacja w odniesieniu do zabytków inżynierii i techniki jest szczególnie skomplikowana ze względu na znaczne zróżnicowanie zasobu (chronologiczne, typologiczne, technologiczne) a także jego szerokie spektrum: od obiektów ruchomych po wielkoprzestrzenne zespoły budowlane i krajobrazy.

Kluczowe jest właściwe rozpoznanie zasobu zabytków inżynierii i techniki, a następnie ich waloryzacja na podstawie eksperckiej wieloaspektowej analizy porównawczej, odniesionej do innych obiektów analogicznych typologicznie w danym okresie czasu i/lub w skali terytorialnej, np. gminnej, powiatowej, wojewódzkiej, regionalnej, krajowej, euroregionalnej, europejskiej, globalnej. Powinny to być działania kompleksowe, wykonane przez specjalistów, mających doświadczenie w zakresie dziedzictwa przemysłowego. Najlepszym rozwiązaniem byłoby tworzenie interdyscyplinarnych zespołów z udziałem zapraszanych ekspertów zewnętrznych. Za takich należy rozumieć także technologów produkcji czy byłych pracowników przedsiębiorstw, których wiedza z zakresu technologii jest zazwyczaj bezcenna. Na taką potrzebę wskazywano już pół wieku temu. Dzisiaj sytuacja jest znacznie trudniejsza. Gwałtowna deindustrializacja kraju sprawiła, że w odniesieniu do wielu gałęzi przemysłu została zniszczona naturalna ciągłość przepływu wiedzy technicznej. Współcześnie znajomość tradycyjnych rozwiązań inżynierskich i technologicznych to domena osób w coraz bardziej podeszłym wieku.

Szczególną uwagę przywiązywać należy do autentyzmu obiektu. W odniesieniu do zabytków techniki i inżynierii będą to przede wszystkim ślady technologii i wyposażenia, które powinny być zachowane i uczytelnione. Specyfiką budowli przemysłowych jest odzwierciedlenie procesów produkcyjnych, nie tylko w postaci ciągów technologicznych, ale także licznych często doraźnych przekształceń. Tego typu nawarstwienia mogą mieć duży walor poznawczy, ale także kształtować specyficzny charakter zabytku, decydujący o jego wyjątkowości. Analogicznie należy postępować w odniesieniu do przejawów codzienności, takich jak brud i naturalne zużycie. Na powyższe kwestie należy zwrócić szczególną uwagę na każdym etapie: waloryzacji, kategoryzacji, zaleceń konserwatorskich, opracowywania i zatwierdzania programu prac przy obiekcie, a także wykonawstwa.

Podejmowanie czynności z zakresu ochrony i konserwacji, a zwłaszcza formułowanie zaleceń i dokonywania uzgodnień konserwatorskich, powinno opierać się o wyniki przeprowadzonej uprzednio analizy wartościującej. Jednak wobec stanu zachowania/przekształceń zabytków techniki i inżynierii ryzykowne byłoby ich dzielenie na kategorie. Tym bardziej, jeśli taka kategoryzacja rodziłaby skutki formalno-prawne, a w szczególności wiązałaby się z dostępem do wsparcia finansowego ze środków publicznych oraz/lub przyporządkowaniem kompetencji różnym organom administracji publicznej.

Warto przypomnieć, że pięciostopniowa klasyfikacja obiektów zabytkowych, obowiązująca w Polsce w latach 1961-1973 ${ }^{28}$, w ocenie wielu specjalistów spowodowała nieodwracalne straty z powodu nieobjęciaochronązabytkówniższychklas, uznanychzaposiadające „minimalnąwartość”. W szczególny

27 Więcej na ten temat w: Kępczyńska-Walczak A., Walczak B. M., „Cyfrowe zasoby wiedzy o zabytkach - teoria i codzienna praktyka” w: Zapłata R. (red.) Cyfryzacja w naukach o przeszłości i ochronie zabytków - analiza potencjału i zagrożeń, UKSW, Warszawa (w przygotowaniu).

28 Łazarowicz S., Sieroszewski W., Przepisy prawa dotyczace muzealnictwa i ochrony zabytków, Ministerstwo Kultury i Sztuki - Zarząd Muzeów i Ochrony Zabytków, Warszawa 1970, s. 108-109. 
sposób dotknęło to zabytki techniki i inżynierii - zaniedbaniu i zniszczeniu uległy m.in. wiatraki oraz liczne obiekty z drugiej połowy XIX wieku. Nawet w obliczu formalnego zrównania wszystkich zabytków w Polsce, lista obiektów poprzemysłowych, które mimo ich bezsprzecznych walorów uległy w ostatnich latach nieodwracalnej dewastacji, jest zasmucająco długa.

Powyższe obawy wynikają zatem z faktu, że mimo upływu czasu wciąż zachowują swoją moc słowa Kazimierza Kimszala, Sekretarza Generalnego Naczelnej Organizacji Technicznej w latach 1963-1967: „Swoistym paradoksem jest fakt, że technika, której czołowa rola w kształtowaniu życia społeczeństw i jednostek ludzkich zyskała powszechne uznanie, nie może się doczekać odpowiedniego uznania dla swoich tradycji i zabytków"29.

W konsekwencji wciąż konieczne jest świadomościowe zrównanie spuścizny poprzemysłowej z innymi typami zabytków. Nie bez znaczenia jest także wskazane wyżej powiązanie z postępem technologicznym i gospodarką. Fizyczny kształt obiektów był determinowany przez proces, któremu służyły. Oznacza to, że wraz z pojawianiem się coraz to nowszych technologii, nowoczesne do tej pory obiekty stają się bezużyteczne bądź też zachodzi konieczność ich przekształcenia w celu dostosowania do aktualnych wymogów. Procesy gospodarcze zaś sprawiają, że tradycyjne gałęzie przemysłu zanikają w Europie. W rezultacie liczne obiekty stają się bezużyteczne, a całe regiony w skrajnych przypadkach pogrążają się w kryzysie ekonomicznym związanym z zanikiem funkcji przemysłowych. Luis Loures wskazuje, iż jedynie nieliczne ośrodki miejskie uniknęły likwidacji fabryk. Powszechność procesów deindustrializacyjnych w cywilizacji zachodniej sprawia, że „fizyczna i funkcjonalna dekadencja przyczynia się do negatywnej percepcji przestrzeni” znacznych obszarów ${ }^{30}$.

Kolejna kwestia to kanon piękna. Mimo, że od wielu lat ochroną konserwatorską obejmuje się obiekty istotne dla kultury nie tylko ze względu na ich walory estetyczne, to jednak budowle związane z przemysłem są niejednokrotnie dalekie od powszechnie akceptowalnych rozwiązań architektonicznych i plastycznych. Tim Edensor zauważa, że opustoszałe tereny poprzemysłowe są fascynujące jedynie dla wąskiej grupy osób, dla których estetyka upadku stanowi rodzaj „współczesnego gotyku”, wywołującego nastrój „postindustrialnej nostalgii” ${ }^{1}$. Natomiast według Johna R. Shorta miasta poprzemysłowe są zazwyczaj postrzegane jako przestarzałe, przebrzmiałe i zanieczyszczone. Dlatego w wielu przypadkach starano się rozwiązać problem negatywnego wizerunku poprzez zerwanie $\mathrm{z}$ industrialną przeszłością i radykalne przekształcenie miasta ${ }^{32}$.

Z powyższych uwag wynika, że ochrona konserwatorska obiektów inżynierii i techniki może być zarzewiem konfliktów społecznych. W najlepszym razie społeczna akceptacja działań konserwatorskich będzie utrudniona ze względu na ich odpychający wygląd (często wynikający z zaniedbania bądź też doraźnego dostosowywania do potrzeb produkcji). Co więcej, zainteresowanie służb konserwatorskich zbiega się zwykle w czasie z problemami gospodarczymi związanymi

29 W przedmowie do: Jasiuk J., Pazdur J. (red.), Muzea i zabytki techniki... (podkreślenia B. M. Walczak)

30 Loures L., „Industrial Heritage: the past in the future of the city”, WSEAS Transactions on Environment and Development, nr 8, tom 4, 2008, s. 687-696.

31 Edensor T., Industrial Ruins: Spaces. Aesthetics and Materiality, Berg, Oxford-Nowy Jork 2005; por.: G. Campagnol, „Post-Industrial Sites as Canvas”, Architecture and Urbanism, nr 521, 2014, s. 70-75.

32 Short J. R., „Urban Imagineers: Boosterism and the Representation of Cities” [w:] Jonas A.E.G., Wilson D. (red.), The Urban Growth Machine. Critical Perspectives, Two Decades Later, State University of New York Press, Nowy Jork 1999, s. 37-54. 
z upadkiem przemysłu. Biorąc pod uwagę typową dla tradycyjnych ośrodków produkcyjnych koncentrację zakładów na stosunkowo niewielkim obszarze, można wskazać, że nie tylko powstanie obiektów było ściśle powiązane z procesami gospodarczymi, zależy od nich także skuteczna ochrona dziedzictwa przemysłowego.

Jednak zabytki inżynierii i techniki mogą mieć szereg pozytywnych konotacji. Są materialnym świadectwem postępu, innowacyjności i przedsiębiorczości. Dokumentują także wiedzę o dawnej technologii. W szerszym ujęciu obrazują kulturę pracy oraz życie codzienne w przemysłowych regionach kraju. Dlatego trudno sobie wyobrazić wiele miejsc bez zachowania obiektów związanych z rozwojem przemysłowym, gdyż decydują one o ich odrębności i tożsamości. Co więcej, ze względu na bezpowrotną utratę funkcji, ochrona obiektów poprzemysłowych wiąże się z koniecznością ich adaptacji do nowych potrzeb. Trzeba zauważyć, że działania tego rodzaju mogą w znacznym stopniu przyczynić się do odnowy obszarów kryzysowych - zjawiska charakterystycznego dla dawnych okręgów przemysłowych. Naczelnym zadaniem jest zatem budowanie społecznych więzi ze spuścizną przemysłową oraz jej umiejętne wykorzystanie w procesie rewitalizacji33 ${ }^{33}$

$\mathrm{W}$ świetle powyższego skuteczne działania ochronne wymagają $\mathrm{w}$ pierwszej kolejności świadomościowego zrównania rozumienia wartości dziedzictwa przemysłowego z innymi typami zabytków. Następnie konieczne jest zintegrowanie działań na rzecz konserwatorskiej ochrony zabytków techniki, inżynierii i przemysłu ze współczesnym życiem społeczno-gospodarczym, przy jednoczesnym zachowaniu ich wartości kulturowych, zazwyczaj trudniejszych do identyfikacji aniżeli w przypadku innych obiektów historycznych.

Współczesne kierunki rozwoju doktryn konserwatorskich, preferujące ochronę zintegrowaną, obszarową, uwzględniającą różnorodne aspekty przeszłości nie tylko jako przedmiot zainteresowania konserwatorów, ale także integralny element rozwoju danego obszaru ${ }^{34}$, jak również wskazujące na społeczny wymiar dziedzictwa ${ }^{35}$, w co raz większym stopniu dostrzegają znaczenie dziedzictwa przemysłowego oraz jego specyfikę.

33 Według Ustawy z dnia 9 października 2015 r. o rewitalizacji (Dz.U. 2015, poz. 1777), rewitalizacja stanowi proces wyprowadzania ze stanu kryzysowego obszarów zdegradowanych, prowadzony w sposób kompleksowy, poprzez zintegrowane działania na rzecz lokalnej społeczności, przestrzeni i gospodarki, skoncentrowane terytorialnie, prowadzone przez interesariuszy rewitalizacji na podstawie gminnego programu rewitalizacji.

34 Zalecenie UNESCO w sprawie historycznego krajobrazu miejskiego, Paryż 2011.

35 Konwencja ramowa Rady Europy w sprawie znaczenia dziedzictwa kulturowego dla społeczeństwa, Faro 2005. 